\title{
DANTE and MILTON
}

\author{
The Commedia \\ and Paradise Lost
}

IRENE SAMUEL

Hunter College

Cornell University Press

ITHACA, NEW YORK 


\section{DANTE and MILTON}

The Commedia and Paradise Lost 



\title{
DANTE and MILTON
}

\author{
The Commedia \\ and Paradise Lost
}

IRENE SAMUEL

Hunter College

Cornell University Press

ITHACA, NEW YORK 
Copyright (C) 1966 by Cornell University

All rights reserved

CORNELL UNIVERSITY PRESS

First published 1966

All quotations from Dante's The Divine Comedy used in this book are from The Divine Comedy, Temple Classics Edition, published in three volumes by E. P. Dutton \& Co., Inc., New York, and J. M. Dent \& Sons Ltd, London, with English-Italian text: the Italian edition by $\mathrm{H}$. Oelsner; English translation by J. A. Carlyle, Thomas Okey, and P.H.Wicksteed.

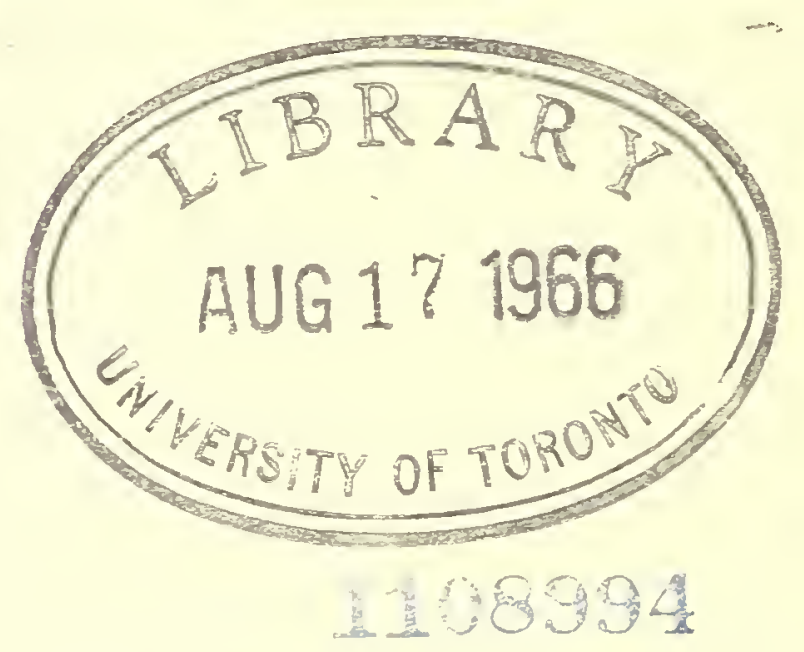

Library of Congress Catalog Card Number: 65-23220

PRINTED AND BOUND IN THE UNITED STATES OF AMERICA BY THE MAPLE PRESS COMPANY 